\title{
Resurrecting the Alien Director: Jean-Pierre Jeunet in Hollywood
}

\author{
Elizabeth Ezra
}

The fourth film in the Alien quartet, directed by French filmmaker JeanPierre Jeunet, has had a somewhat different reception from the other films in the series. Alien Resurrection did poorly at the box in both Britain and the United States, where critical reaction, too, was much less enthusiastic than toward the previous Alien films. In short, Jeunet's film has been largely dismissed by English-speaking fans and critics of the previous films in the series. What is it about this film that has provoked such scorn? Was it poorly directed, or was it some other aspect of the film that rubbed Anglo-American critics and audiences the wrong way? This essay will suggest that the anxieties that the film elicited among critics actually mirror some of the themes played out within the film.

In this film, Ripley, played as ever by Sigourney Weaver, has been recreated out of a fragment of DNA retained from her body at the time of her death two hundred years earlier (in this, the film reveals intertextual references to both Jurassic Park and another English-language film made by Jeunet's compatriot Luc Besson, The Fifth Element [1997]). But this is not the only resurrection to which Alien Resurrection bears witness. In addition to the resurrection of Ripley and her alien offspring, there is also that of the Alien series itself, which viewers were led to believe had ended when the central character plunged to her death at the end of the third film. Finally, and most important for our purposes here, the film also resurrects the tradition of the French filmmaker abroad. 
When Jeunet, who had directed, with Marc Caro, such popular and well regarded French films as Delicatessen (1991) and La Cité des enfants perdus (1995), went to Hollywood in 1997 to film Alien Resurrection, he was following in the footsteps of a long line of directors who left France to make films abroad, most often in Hollywood but sometimes in Britain. The cosy partnership between French filmmakers and the English-language film industry goes back at least to 1903, when Georges Méliès established a branch of his Star-Film production company in New York, and sent his brother Gaston first to Texas, and then to Southern California, to set up studios that would make Westerns and adventure films (see Méliès 1988). After the critical and commercial failure of his 1934 Le Dernier millionnaire, René Clair went to Britain, where he made The Ghost Goes West (appropriately enough, about a Scottish phantom who relocates to the U.S. when an American buys his castle haunt and ships it to Florida), and then Break the News (1938) before going to Hollywood, where his films included the the 1941 Flame of New Orleans, with Marlene Dietrich playing a French woman coming to the U.S. to flee a chequered past, the 1942 I Married a Witch, starring Veronica Lake (the film's publicity slogan: 'She knows all about love potions... and lovely motions!'), the 1943 Forever and a Day, about an American in Britain, and the 1944 It Happened Tomorrow, about a reporter who can see into the future (see Lebrun 1987). During the Occupation, several French filmmakers fled to Hollywood, including Jean Renoir and Julien Duvivier, who made both propaganda films and features, and Jacques Tourneur, whose Cat People, about a beautiful young emmigrée to the U.S. (played by Simone Simon, doing her best Serbian accent), on whom the 'old country' exercises an atavistic attachment, achieved cult B-movie status. Truffaut, following in Clair's footsteps, made 
Fahrenheit 451 in Britain in 1966; Roger Vadim made Barbarella, a French-ItalianAmerican coproduction filmed in English, in 1968. These films are typical of the majority of films made by French émigré directors, many of which use fantastical means to allegorize personal or political alienation. Bertrand Tavernier's Death Watch, filmed in Glasgow in 1979, starred a youthful Harvey Keitel as a man who, by means of a camera implanted in his retina, secretly films an apparently dying Romy Schneider in order to boost the ratings of a sensationalistic 'candid camera' television show. Both Keitel and Schneider play immigrants, he from the U.S. and she from France. The thematization of cultural alienation was again taken up in Luc Besson's Léon (1994), made in the United States, about a French hitman, isolated in New York, who befriends and teaches a little girl the tricks of his trade.

Janet Bergstrom has noted of the directors who worked in the U.S. during the Occupation that '[i]n America, these directors were always referred to and always referred to themselves, as French' (89). National distinctions were still maintained over fifty years later during the making of Alien Resurrection. In interviews, Jeunet spoke of the differences he encountered between the Hollywood system and French production methods: “Aux États-Unis, tout est multiplié par quatre. Il y a quatre fois plus de gens géniaux, mais aussi quatre fois plus de gens mauvais" [In the U.S., everything is multiplied by four. There are four times the number of fantastic people, but also four times more hopeless ones] (Campion 1997). Most notable to Jeunet was the 'combat quotidien très lourd, à chaque plan, chaque prise' [the intense daily struggle, during every shot, every take] between the director's aspirations and Hollywood's insistence that a film appeal to the widest possible audience (Rouyer and Tobin 1998: 98). The 
Hollywood establishment seemed foreign to Jeunet, and, perhaps not surprisingly, this perception was reciprocated. Jeunet used an interpreter on the set, and there reportedly were 'language difficulties' (Thomson 1998: 136)— though, where Thomson hints that the fault may have been Jeunet's, Jeunet himself lays rather more blame on the interpreter, who

ne comprend rien à un plateau et restait stupidement devant la caméra au moment de tourner. De plus, victime de migraines atroces, elle se protégeait des fumées avec un masque à gaz. . J' ai donc appris à dire tighter, wider, faster, et surtout shut the fuck up. (Bayon, Libération 12-11-97, p. 2)

[didn't understand anything about working on a set, and who stood dumbly within camera range while we were shooting. What's more, since she suffered from serious migraines, she wore a gas mask to protect herself from the smoke in the studio... So I learned how to say in English 'tighter', 'wider', 'faster', and especially 'shut the fuck up'.]

It is worth noting that the film did significantly better outside the United States, grossing $\$ 109,200,000$ on its first run (compared with $\$ 47,748,000$ in the U.S., which was consired a failure in light of the film's $\$ 70$ million budget). Abroad, the film was considered to be another big-budget American action film, rather than a film directed by a Frenchman. The one exception to the film's 
image abroad, of course, was France, where the film was recuperated into the French cinematic tradition, having been directed by one of 'their own' (see, for example, 'Vive la France!', Annie Coppermann, Les Echos 17-11-97). Not unsurprisingly, the French press depicted Jeunet's relationship with Hollywood in terms reminiscent of David and Goliath: 'Alien, la résurrection, outre son intrigue fonctionnelle, raconte aussi cela: le conflit du réalisateur et de son univers particulier. . . avec une machinerie titanesque qui entend satisfaire les fantasmes des spectateurs internationaux. ..' [Alien Resurrection, aside from its perfunctory plot, tells the story of the conflict between the director and his surroundings... with a colossal production designed to appeal to international viewers] (Olivier de Bruyn, L'évènement, 13-11-97). The French director's experience of estrangement is evoked in the final words of the film itself, uttered by Ripley when, gazing at earth, Call asks her, 'What happens now?' and she replies, 'I don't know. I'm a stranger here myself'.

Jeunet may have wondered at the excesses of Hollywood, but his sense of bemusement was exceeded by the widespread perception among American critics that Jeunet's film was itself a study in excess. The earlier films are considered by many to be a self-contained trilogy in relation to which the fourth film stands as a superfluous supplement. Why has this film been so often depicted as either an unnecessary interloper or merely a placeholder or stepping stone for the 'real' continuation of the story? The film's status as 'superfluous' is doubtless linked at least in part to the perception that its content is characterized by excess: the film has been said to contain too many aliens, too much slime, too much horror; it is 'over-the-top', 'excessively gory and goo-splattered' (Christine James, Boxoffice Movie Review Search, Internet Movie Database). According to 
the Washington Post, Alien 4 'may not be the scariest movie ever made, but it certainly is the gloppiest. It's so drippy and slippery you'll feel that you're hiding in Kevin Costner's nasal passages during the filming of Waterworld' (Stephen Hunter, 'Alien Resurrection: Birth of the Ooze', November 26, 1997). The film is also 'overloaded with ideas' (Laura Miller, Salon, Nov. 26, 1997)—a familiar criticism of French intellectualism.

Alien 4 was depicted, in the American press, as exhibitionistic, too eager to display its graphic goo. The film is thus implicitly compared to 'The Betty', the pirate ship that just won't quit: at the end of the film, we see the ship's logo, a 1940's-style cheesecake pinup picture of a reclining woman. Like the Betty, the film comes back for more, stays too long, and shows too much. Kenneth Turan, a film critic for the Los Angeles Times, referred to The Betty as a 'tramp freighter' (Los Angeles Times, Wednesday November 26, 1997). Alien Resurrection itself has been criticized for leaving nothing to the imagination. Reviewer Paul Tatara implicitly compared the film's display of gore to a striptease: 'In Alien Resurrection, most of the screen time is filled with churning blobs of vain-covered guts, heads getting bashed open, and people being sucked into massive piles of entrails. And lots of people in the theater when I watched it were hootin' and hollerin' like it was the second coming of Gypsy Rose Lee' (CNN Interactive, November 20, 1997; reprinted on www.chez.com/jeunetcaro/2english/film/alien4/critiques.html). Where the first Alien was a striptease, revealing its secrets a little at a time and playing a game of hideand-seek, Alien Resurrection is pornographic, getting it all out in the open. The French press dwelled on the hint of erotic attraction between Ripley and Call, 
and on the suggestion of incest between Ripley and her alien grandchild: 'Une histoire d'amitié (amoureuse) entre une clonesse et une androïde qui mériterait de se terminer au lit' [The story of a loving relationship between a cloness and an android, which suggests that it will end under the covers], according to L'Express (Jean-Pierre Dufreigne, 13-11-97); 'Film lesbien', according to L'évènement (13-1197). The English-speaking press largely failed to pick up on these aspects on the film, or at least to write about them-with the exception of the film critic David Thomson, who, rather than discuss the film itself, devotes most of the chapter on this film in his book The Alien Quartet to presenting his own screenplay for a film that he would have preferred to see made: 'Ripley, in a long, gold-coloured skirt, but naked above the waist, is sitting back in a chair eating figs... [T] he ripeness runs down her chin and falls on the healed scar beneath her breasts' (Thomson 1998: 155). Thomson's alternative Alien Resurrection is a soft-porn movie, a Barbarella does Dallas: in a 'five-star spaceship', Ripley, with her maker's 'fine hand on her behavioural controls, has become a kind of space numph, a sexual performer capable of breaking her own records at every outing' (159).

Alien 4 perhaps invites this kind of voyeuristic speculation because, in its very excess, the film is feminized (i.e., represented as feminine). The film's status as a monstrous alien is linked inextricably to this feminization. The fourth film in the Alien series is thought of as a departure from tradition; it is considered to be lacking in relation to a norm, and is often compared to its predecessors in terms that evoke classic accounts of sexual difference. For example, one critic summed up the qualities of the film thus: " "Alien" Sequel looks great, if gory, but doesn't have much brains', and compared the film to 'a clumsy, plodding child having a big hissy fit' (Peter Stack, San Francisco Chronicle, 26-11-97, p. E1). In the on-line 
magazine Salon, Laura Miller called the film 'hopelessly chatty, confusing and overblown' (Nov. 26, 1997). The word 'chatty' is a stereotypically feminizing one (and an inapt one, because this film is actually short on dialogue). The Los Angeles Times called the film 'overstylized', and compared its underwater chase scene to 'an Esther Williams movie' (She's Alive! It's Alive!', Kenneth Turan, 2611-97. The largest daily newspaper in the United States suggested that Wynona Ryder, who plays a young mechanic later revealed to be a robot, was too frail and feminine to be battling aliens, calling her 'as much of an action hero as Julie Nixon would be, going way out of her element as a member of the freighter crew' (Mike Clark, USA Today, 12-01-98).

A brief examination of some of the film's themes and imagery reveals that the association between inhumanness and femininity applies to Ripley and Call alike. When Call sneaks in on Ripley in order to attack her, Ripley stabs herself in the hand, to demonstrate that she is not entirely human and can withstand bodily invasion. This scene literally prefigures the hole in a still-surviving Call's abdomen that signifies her own robotic inhumanity. The hole in Call's middle in turn recalls the sight of Ripley's ravaged abdomen at the beginning of the film, when the alien baby is ripped from her body. Thus, at the same time that these incisions reveal the inhumanness of these characters by demonstrating their imperviousness to ordinarily fatal, or at least painful, wounds, they also mark them as feminine, 'making women' of them-which, Marjorie Garber reminds us, means to have intercourse with (Garber 1993: 93) — by suggesting the reproductive organs.

As in the three preceding films in the series, scenes of parturition abound in Alien Resurrection (for discussions of such imagery in this and the earlier films, 
see Penley 1989: 133-34; Greenberg 1991: passim; Zwinger 1992: passim; Creed 1993: 16-30, 51, 52; and Eaton 1997: 6-9). These terrifying birth images equate feminine reproductive biology with monstrosity. As we have seen, viewers need wait no longer than the film's second scene to see a team of scientists perform a caesarian on Ripley in order to retrieve the slimy alien baby that has been growing inside her. (Indeed, one of the reviews of the film, reinforcing Elaine Showalter's observation that visual representations of medical procedures performed on women have often had a somewhat pornographic function (Showalter 1991: 131-37), warns potential viewers that it contains not only nudity and profanity, but 'graphic surgery' [Desson Howe, The Washington Post, 28-1197]). After the caesarian with which the film opens, the birth scenario is repeated practically ad infinitem, and certainly ad nauseam, as we are treated to the sight of alien and half-alien creatures emerging from the ribcage first of a male human, and then, dispensing with the need for human hosts, from enormous cocoons. Similar images show the pesky creatures bursting up through the floor. All of the viscous aliens sport menacingly sharp teeth, evoking none too subtly a nightmare vision of female genitalia constantly threatening to bite off a head or other protruding male member. It is almost as if the film's target audience were composed of academic viewers, or film critics with a textbook grounding in psychoanalysis under their belts.

As for Ripley, she may be both a monster (an alien) and a human, but it is the monstrous side of her that is equated with femininity, or perhaps the woman in her that is monstrous. Some feminist film critics have posited an identification between the monster in horror films and the female victim-protagonist (Williams 1984; Hayward 1990; Creed 1993). Linda Williams (1984) writes that 'in the rare 
instance when the cinema permits the woman's look, she not only sees a monster, she sees a monster that offers a distorted reflection of her own image' (568). This perfectly describes Ripley in Alien Resurrection as she encounters the seven previous botched attempts to clone her, seven pitifully deformed creatures (also portrayed by Sigourney Weaver) who are quite literally so many 'distorted reflection[s] of her own image'. Ripley reacts to this nightmarish vision by mercifully destroying herselves, provoked by one of the still-conscious prototypes who is tied to an operating table, and who silently implores her to put an end to her misery. Ripley's humane act of euthanasia prompts a male crew member to shake his head incomprehendingly and muse, 'Must be a chick thing'.

Yet, in the logic of this film and others like it, the most monstrous thing about these women is their 'masculinity', their phallicized status. The holes that riddle this film are also figured, in all their sexual and gendered connotations, in the hoop through which Ripley sinks a basketball, out-performing her macho male opponent in a show of 'masculine' prowess. This moment in the film marks the beginning of Ripley's 'phallicization', her journey on the road to becoming what Carol Clover (1987) has called the 'Final Girl' in horror films. Clover mentions the first two Alien films, in which she identifies Ripley as the Final Girl. But what about Alien Resurrection? In the scenes of incision described above, both Ripley and Call resemble victims in slasher films. Ripley indeed survives until the end of this film, evolving from her helplessness at the beginning of the film when she is splayed out on an operating table with her abdomen cut open, a vulnerable position if there ever was one. She is in captivity, told that she was resurrected merely in order to bring the alien baby inside her to term, but that, beyond that act, she is superfluous, 'a meat by- 
product'. Ripley herself, like the film in which she stars, is thus from the start depicted as excessive. But she soon turns the tables on her captors, eventually leading them-or those who manage to survive-to safety, demonstrating superior heroism and leadership skills. ('Ripley —surely the most "masculine" heroine ever' ['Alien Resurrection: She Lives', Desson Howe, The Washington Post, 28-11-97].) The shift in power dynamic occurs during the game of one-on-one basketball with the macho, taunting crew member Johner, who is put in his place as Ripley beats him at his own game, finally hitting him in the groin with the ball. The symbolism regarding who has the phallic upper hand here is so unmistakable as to be parodic, as it is again later in the film when Ripley throws a long, dismembered alien tongue to Call, literally passing her the phallic baton. Call, played by Winona Ryder, is clearly the next generation of Clover's 'Final Girl', a potential victim in a horror film who survives the terrors that come her way by becoming 'phallicized'; it is to her that the more mature Signourney Weaver seems to be passing the reins. As one (male) reviewer put it, 'Quand elles [Ripley and Call] filent un coup de genou bien placé ou un simple gnon au menton, ça couine dans la gent mâle. Notre épine dorsale frémit' [Whenever they knee someone in a strategic area or even konk someone on the chin, the male members of the audience let out a squeal. Shivers run down our spine] (Jean-Pierre Dufreigne, L'Express 13-11-97). Later in the film, Call manages to dismantle the ship's central computer, helpfully named 'Father' (whereas the computer in the first Alien was called 'Mother'). When she announces, 'I've killed Father', it is hard to imagine a more overtly phallicizing Oedipal image, framed in such terms. Moreover, as Clover noted long before this film was made, the Final Girl is boyish and characterized by "smartness, gravity, competence in 
mechanical and other practical matters, and sexual reluctance" (Clover 1987: 204), traits that aptly characterize Call, a mechanic with a short, boyish haircut who rejects the physical advances of the men on the ship. There is one problem with this reading, however: Call is not only a girl; she is also a robot. Like Ripley, she is a hybrid creature. And, like Ripley, Call's moment of truth-the moment we are shown her gaping, oozing chest cavity—involves a lot of slime.

For this, above all, is the significance of Alien Resurrection : it is a film about slime. It's not a pretty picture. This excrescence is the stuff of abjection, which results, according to Julia Kristeva, from a crisis in classification, from the failure to differentiate adequately between oneself and... that thing : the abject is '[c]e qui ne respecte pas les limites, les places, les règles. L'entre-deux, l'ambigu, le mixte' [that which does not respect limits, positions, rules. The inbetween, the ambiguous, the hybrid] (12). The abject results from the crossing of borders; it is what falls through the cracks. This failure to respect boundaries, whether generic (is the film sci-fi or horror?), national (is the film French or American?), gendered (is Ripley masculine or feminine?), sexual (is Ripley the alien's parent or its lover?), or biological (is Call human or android; is Ripley human or alien?) is precisely what makes the film so unsettling to critics, and precisely what makes Ripley so menacing to her fellow travellers. Like Ripley, Alien Resurrection is a freakish hybrid, part French and part 'normal' (read 'Hollywood'), part alien and part domestic product. The film's plot thus mirrors the story of its reception, with the film itself playing the role of the monstrous alien.

By way of conclusion, I wish to make clear that I am not suggesting that Alien Resurrection is in any way more 'French', or more 'European', than its 
Hollywood counterparts-indeed, such an assertion would be analagous to, and as critically dubious as, the attribution of 'feminine' traits to a film made by a woman. What I am suggesting is, first, that the film's Anglo-American reception may have something to do with certain perceptions of Frenchness abroad (at least among the popular press), and second, that the problematics of 'outsiderness' and alterity informing the film's reception appear in thematic and narrative form within the film itself. Whether the film's critics were taking their cue, however unconsciously, from the film, or, alternatively, whether Jeunet anticipates the position that he and his film would come to occupy within the critical imaginary, cannot be determined. What is clear, however, is that the film's reception demonstrates the continued relevance and potency of the science-fiction alien as a metaphor for anxieties surrounding national, cultural, and sexual difference. 


\section{REFERENCES}

Bergstrom, J. (1998), 'Emigrés or exiles? The French directors' return from Hollywood', Hollywood and Europe: Economics, Culture, National Identity: 1945-95 (eds. Geoffrey Nowell-Smith and Steven Ricci), London, BFI Publishing.

Campion, A. (1997), 'Jean-Pierre Jeunet ressuscite les “aliens"', Journal du dimanche (9 November).

Clover, C. (1987), 'Her Body, Himself: Gender in the Slasher Film', Representations 20 (Fall), pp. 187-228.

Creed, B. (1993), The Monstrous-Feminine: Film, Feminism, Psychoanalysis, London, Routledge.

Eaton, M. (1997), 'Born Again', Sight and Sound, 7:12 (December), pp. 6-9.

Garber, M. (1993), Vested Interests, London, Penguin Books.

Greenberg, H. R., M.D. (1991), 'Reimagining the Gargoyle: Psychoanalytic Notes on Alien', Close Encounters: Film, Feminism and Science Fiction (eds. Constance Penley et al.), Minneapolis, University of Minnesota Press, pp. 83-104. 
Hayward, S. (1990), 'Cocteau's Belle is not that Bête: Jean Cocteau's La Belle et la Bête', French Film: Texts and Contexts (eds Susan Hayward and Ginette Vincendeau), London, Routledge.

Kristeva, J. (1980), Pouvoirs de l'horreur, Paris, Editions du Seuil.

Lebrun, D. (1987), Paris-Hollywood, [Paris?], Fernand Hazen.

Méliès, Gaston (1988), Le Voyage autour du monde de la G. Méliès Manufacturing Company, Paris, Association ‘Les Amis de Georges Méliès.

Mulvey, L. (1975), 'Visual Pleasure and Narrative Cinema', Screen, 16: 3 (Autumn).

Penley, C. (1989), The Future of an Illusion: Film, Feminism, and Psychoanalysis, London, Routledge.

Rouyer, P. and Y. Tobin (1998), 'Entretien Jean-Pierre Jeunet', Positif 443 (January), pp. 95-99.

Showalter, E. (1991), Sexual Anarchy, London, Bloomsbury.

Thomson, D. (1998), The Alien Quartet, London, Bloomsbury. 
Williams, L. (1992), 'When the Woman Looks', reprinted in Film Theory and Criticism, fourth edition (ed. Gerald Mast et al.), New York, Oxford University Press. First published in 1984.

Zwinger, Lynda. 'Blood Relations: Feminist Theory Meets the Uncanny Alien Bug Mother'. Hypatia, vol. 7, no. 2 (Spring 1992), pp. 74- 90. 